\title{
COMPETITIVENESS OF SOYBEAN BUSINESS FARMING ANALYSIS IN GROBOGAN REGENCY CENTRAL JAVA PROVINCE
}

\author{
Nurul Widya Anggraeni ${ }^{1)}$, Wiludjeng Roessali ${ }^{1)}$, Hery Setiyawan ${ }^{1)}$ \\ ${ }^{1}$ Study Program of Agribusiness, Faculty of Animal and Agriculture Science, University of Diponegoro \\ email: nurulwidya96@gmail.com
}

\begin{abstract}
Soybean is one of the strategic commodities. To fulfill the increasing of domestic demand, it must be supplied from imports because domestic production is unsufficient. In addition, lower price of imported soybean has effected in competition of domestic farmers to get profit. Demand of soybean in the international and domestic market has always increased. Indonesia has imported soybeans to fill domestic soybean demand. This condition will have an impact on the decline in farm income due to soybean import. The aims of this study were to analyze the level of private profitability and competitiveness of soybean farming in GroboganRegency.This research used survey research method with number of samples taken through simple random sampling of 100 soybean farmers. Data were analyzed by Policy Analysis Matrix (PAM). The results showed that private profitability of soybean farming in Grobogan Regency was Rp1.690.393,22 per MT. Two indicators to measure the competitiveness were Private Cost Ratio (PCR) and Domestic Resources Cost Ratio (DRCR). PCR value was 0,75 which showed that soybean farming in Grobogan Regency was more competitive and Domestic Resources Cost Ratio (DRCR) showed 0,88. It showed that soybean farming had a comparative advantage.
\end{abstract}

Key words :Competitiveness, PAM, Soybean farming.

\section{INTRODUCTION}

Agriculture has an important role to support food source for survival of the persons and importable exchange earner in Indonesia. The development of the agricultural sector, especially the food crop sub-sector, leads to an increase in production so that it will create food self-sufficiency which will have an impact on increasing the income of farmers as well. The importance of development in the agricultural sector is an effort to improve persons's welfare, create job, develop regions, increase added value, competitiveness and export. The development of agricultural sector is inseparable from government policy and the role of farmers in increasing production. Government policies must support the increase in productivity yields, among others, provision of inputs, standard pricing, improvement of agricultural product distribution line, improving the performance of agricultural institutional function (Nugraha, 2015).

Soybean is one of the highlighted commoditybecause the protein content is high enough to improve persons's nutrition. Most of the domestic soybean is used as raw materials for food processing industries such as tofu, tempeh, soysauce, tauco, and chips. The development of processed food can be used as a source of importable exchange in relation to export of processed food products (Rukmana and Yuniarsih, 2012). In relation to increasing food needs, soybean needs will also continue to increase every year. Domestic soybean needs are supplied from domestic and importable production (Ratna et al., 2013).

Central Java is the largest soybean production center in Indonesia with a contribution of $14.03 \%$. Soybean production in Grobogan Regency reached 48,316 tons 
in 2016, it showed that this production contributed $38.7 \%$ of the total production in Central Java (BPS, 2016). Soybean production center in Central Java are in Grobogan Regency. Pulokulon and Purwodadi District are the areas that have the largest harvest area and yields in Grobogan Regency. Both of these subdistricts are known as the best soybean producers of the Grobogan variety with a productivity of 2.3 tons per hectare. This productivity is the highest compared to other regions which are only able to produce 1 to 1.5 tons per hectare (Central Statistics Agency, 2014). Fulfillment of domestic soybean needs cannot be separated from farming activities carried out by local farmers (Sahaya, 2014). Soybean farming business done locally and profitable and has comparative and competitive advantages will be better than just relying on imports (Sari and Prajanti, 2016).

The profits received by farmers are determined by the price of production (output) and the price of the production factor (input) received by farmers. Many farmers in Grobogan Regency cultivate soybeans and make it as the main source of income (Sahaya, 2014). This research was conducted with the aim to determine whether soybean cultivation in Grobogan Regency is profitable and has competitiveness.

\section{RESEARCH METHOD}

Determination and sampling. The study was conducted on November 2017. The method used in this study was a survey, collecting information through several samples from the population. Sampling on soybean farming was performed by simple random sampling technique, where each soybean farmer had the same possibility of being selected as a sample. Farmers made as respondents were in Nambuhan Village, Purwodadi District and Panunggalan Village, Pulokulon District. The two villages used in this study were villages that routinely conduct soybean farming every year. In addition, the two villages also won the national soybean agribusiness competition, Panunggalan village won in 2011 and Nambuhan village in 2016. The number of samples was determined by Slovin Formula because the population was known (Riduwan and Engkos, 2011) with a 10 percent error limit. The number of farmers in Nambuhan village was 1,793 farmers and in Panunggalan Village was 1,577 farmers. The total population of farmers in Nambuhan and Pulokulon Villages was 3,450 farmers, so there were 100 respondents obtained by using Slovin Formula. Data obtained through interviews with respondents using questionnaires .

Table 1. Determination of Production Cost Allocation to Domestic and importable Component

\begin{tabular}{clcc}
\hline No & & Domestic $(\%)$ & Importable $(\%)$ \\
& & 100 & 0 \\
\hline 1 & Seed & 0 & 100 \\
2 & Fertilizer & 95 & 5 \\
3 & Pestiside & 100 & 0 \\
4 & Man power & 100 & 0 \\
5 & Land & 100 & 0 \\
6 & Equipment & 100 & 0 \\
& Hoe & 100 & 0 \\
& Sickle & 0 & 100 \\
& Bucket & 100 & 0 \\
& Sprayer & & \\
7 & $*$ Other Cost & &
\end{tabular}

Source: Processed Primary Data, 2018. 
Determination of cost allocation. Tradable inputs in this study were seeds, fertilizers, pesticides and agricultural equipment (sprayers) while the non-direct inputs used in this study were organic fertilizers, labor, and other costs. In addition to these two inputs, there were traded inputs and nontraded inputs called indirect trade. Inputs belonging to the indirect trade in this study were pesticides which were calculated from the components of domestic cost as much as 95 percent and importable cost as much as 5 percent $\mathrm{f}$. Seed input was included in the 100 percent domestic component because farmers in Grobogan Regency produced their own soybean seeds domestically. The allocation of production cost for soybean farming can be seen in Table 1 .

Data Analysis. The analysis used to answer the objectives of the research was Policy Analysis Matrix (PAM). The analysis was used to analyze the benefits of private farming and analyze the extent to which soybean competitiveness in Grobogan viewed from competitive advantage (financial) and comparative advantage (economics) and analysis of the impact of government policies that affects input and output on commodities.

Determination of social price. All inputs and outputs were set with two price levels, namely private prices (market) and social prices. Private price is the price that applies at the time the research was conducted, the actual price (market price) both the price received and paid by farmers, traders or processors that play a role in the farming system (Pearson et al., 2005). prices that occur in a perfectly competitive economy and equilibrium conditions. Unbalanced conditions and market prices are difficult to find, so to obtain values that were close to social prices, adjustments must be made to prevailing market prices.

Output social price is the price of output that occurs in the world market when a free market is applied. Imported commodities are used at border prices, namely CIF (Cost Insurance and Freight), while the exported commodities are used as FOB prices (Free on Board). Soybean is a commodity that is imported, so the social price used was CIF (Cost Insurance and Freight).

The social price of fertilizers used in soybean farming business was Phonska and organic fertilizer. Indonesia has exported Phonska, so the social price or social price of Phonska was calculated using the price of FOB (Free On Board). The social price of manure used was the same as the private price because manure includes non-traded goods.

The pesticide used in soybean farming was Atabron which was a domestic production where the raw material consisted of foreign (importable) and domestic (untradeable) components, according to Kadariah (2001) social price was calculated using the following formula:

$$
\begin{aligned}
& \mathbf{P x}=\mathbf{P}_{\text {importable }}+\mathbf{P}_{\text {domestic }} \\
& \mathbf{P}_{\text {importable }}=\mathbf{a} \times \mathbf{P}_{\text {private }} \times \frac{\text { SER }}{\text { OER }} \\
& \mathbf{P}_{\text {domestic }}=(1-\mathbf{a}) \times \mathbf{P}_{\text {private }} \\
& \mathrm{Px} \quad=\text { pestiside social price }(\mathrm{Rp} / \\
& \text { Packaging) } \\
& \mathrm{P}_{\text {domestic }}=\text { untradeable component } \\
& \text { price ( } \mathrm{Rp} / \text { Packaging ) } \\
& \mathrm{P}_{\text {importable }}=\text { import component price } \\
& \text { ( } \mathrm{Rp} / \text { Packaging) } \\
& \mathrm{P}_{\text {private }} \quad=\text { pestiside private price }(\mathrm{Rp} / \\
& \text { Packaging) } \\
& \text { a = importable component part (\%) } \\
& \text { (1 - a) = domestic component part (\%) }
\end{aligned}
$$

Gittinger (1986) argued that when the labor market competes perfectly, the wage rate in the market reflects the value of its marginal productivity. The labor used by farmers in their business is a temporary and generally uneducated workforce. Determining the social price of the wage of agricultural labor is calculated based on the actual price (private price) adjusted for the value of its marginal productivity. The shadow price of labor was calculated in reference to Siregar's (2009) study, which 
was equal to 80 percent of the wage level in the research area.

The agricultural equipment used in tradeablesoybean farming business was pesticide sprayer. Prayer was an imported item so that social price was calculated using CIF prices. The social price for a tool other than the sprayer used in soybean farming business was the same as the private price because it was a non-traded item. Land was included in the untradable input where the social price of land can be approached through the net income of the best commodity crops commonly planted on the land, the rental value that applies in the local area and the value of land lost due to the project. Determining the social price of land in this study was in accordance with the opinion of Gittinger (1986), namely by using the land rent value that applies in the research area.

Competitiveness Analysis. The Policy Analysis Matrix (PAM) was used to analyze competitiveness and the impact of government policies on soybean farming business. This model is in the form of a matrix that is compiled by including the components of acceptance, cost and profit (Soetriono, 2006). The results of the PAM analysis will provide information about both private and social benefits, the competitiveness of a commodity both from economic efficiency (comparative advantage) and financial efficiency and the impact of government policies on the commodity system. The calculation of the PAM model was done through the PAM matrix found in Table 2. The following.

Criteria for Domestic Resources Cost Ratio (DRCR) were used to test the presence or absence of comparative advantages of soybean commodities. DRCR is an indicator of comparative advantage that shows the amount of domestic resources that can be saved to produce one foreign exchange unit. The system is said to have a comparative advantage if DRCR $\leq$ 1 , and vice versa if the DRCR> 1 does not have a comparative advantage. Competitive advantage is known by using the criteria of Private Cost Ratio (PCR). PCR is a private profitability indicator that shows the ability of a commodity system to pay for domestic resource costs and remains competitive. 1, means the commodity system does not have a competitive advantage.

The impact of government policy can be seen from following indicators :

Government Policy for Output. This policy can be seen from Output Transfer (OT) and Nominal Protection Coefficient on Output (NPCO).

Output Transfer : OT = A-E. Output transfer is the difference between income at private price and revenues at social price. If the value of OT> 0 indicates a transfer from the consumer (community) to the producer, if the OT value is $<0$, then there is no transfer from the consumer to the producer.

Table 2. Policy Analysis Matrix (PAM)

\begin{tabular}{|c|c|c|c|c|c|}
\hline \multirow{2}{*}{ No } & \multirow{2}{*}{ Information } & \multirow{2}{*}{$\begin{array}{c}\text { Output } \\
\text { Revenue }\end{array}$} & \multicolumn{2}{|c|}{ Cost } & \multirow{2}{*}{ Profit } \\
\hline & & & $\begin{array}{c}\text { Input } \\
\text { Tradeable }\end{array}$ & $\begin{array}{c}\text { Input } \\
\text { Nontradeable }\end{array}$ & \\
\hline 1. & Private Price & A & B & $\mathrm{C}$ & $\mathrm{D}$ \\
\hline 2. & Social Price & $\mathrm{E}$ & $\mathrm{F}$ & G & $\mathrm{H}$ \\
\hline 3. & Policy Impact & I & $\mathbf{J}$ & K & $\mathrm{L}$ \\
\hline
\end{tabular}

Source: Pearson et al., 2005. 
Information :

Output Revenue

Output Price

Total Output

Financial Benefit

Economic Benefit

Output Transfer (OT)

TradeableInput Transfer (IT)

Nontradeable Input Transfer (FT)

Net Transfer (NT)

Private Cost Ratio (PCR)

BSD Ratio (DRC)

Nominal Protection Coefficient Output (NPCO)

Nominal Protection Coefficient Input (NPCI)

Effective Protection Coefficient (EPC)

Profit Coeffient (PC)

Subsidy Ratio for Producers (SRP)
(A) $\quad=$ Pq $\times$ Q
$=\mathrm{Pq}$
$=\mathrm{Q}$
(D) $=\mathrm{A}-(\mathrm{B}+\mathrm{C})$
(H) $=\mathrm{E}-(\mathrm{F}+\mathrm{G})$
(I) $\quad=A-E$
(J) $=\mathrm{B}-\mathrm{F}$
(K) $=\mathrm{C}-\mathrm{G}$
(L) $\quad=\mathrm{I}-(\mathrm{K}+\mathrm{J})$
$=\mathrm{C} /(\mathrm{A}-\mathrm{B})$
$=\mathrm{G} /(\mathrm{E}-\mathrm{F})$
$=\mathrm{A} / \mathrm{E}$
$=\mathrm{B} / \mathrm{F}$
$=(\mathrm{A}-\mathrm{B}) /(\mathrm{E}-\mathrm{F})$
$=\mathrm{D} / \mathrm{H}$
$=\mathrm{L} / \mathrm{E}$

Nominal Protection Coefficient on Output $:$ NPCO $=\mathbf{A} / \mathbf{E} \cdot$ NPCO is an indicator that shows the level of government protection against domestic output. If the value of NPCO> 1 indicates a policy that protects domestic output and vice versa. If NPCO $<1$ shows the absence of policies that protect domestic output or disincentive policy .

Government Policy for Input. This policy to find out how much government interference with farmers can be seen from the value of Input Transfer ,Nominal Protection Coefficient on Input and Transfer Factor.

Input Transfer $:$ IT = B-F.Input transfer is the difference between input cost that can be traded at private price and input cost that can be traded at social price. IT value> 0 indicates the transfer from producer farmers to inputtradeable producers, if IT $<0$ shows there is no transfer from producer farmers to input tradeable producers.

Nominal Protection Coefficient on Input : NPCI $=\mathbf{B} / \mathbf{F} . \mathbf{N P C I}$ is an indicator that shows the level of government protection about price of domestic agricultural inputs. Policy is protective against domestic input if the NPCI value is $<1$ or in other words there is a subsidy policy towards input tradeable, if the value of the NPCI is $>0$ then there is no subsidy policy against input tradeable.

Transfer Factor : FT = C-G.Factor transfer is a value that shows the difference in private prices with the social price received by producers for the payment of non-traded production factors. The FT value> 0 indicates that there is a transfer from producer farmers to input-nonradeable producers, and vice versa.

\section{Government Policy for Input and Output}

Effective Protection Coefficient : EPC = (A-B)/(E-F). EPC is an indicator that shows the level of simultaneous protection of output and inputable value. Policy is effective if the EPC value is> 1. The greater the EPC value means the higher the government's protection of domestic agricultural commodities.

Net Transfer : NT = D-H. Net transfer is the difference between the net profit that the producer actually receives and its net social benefits. The NT value> 0 indicates an additional producer surplus caused by government policies applied to input and output, and vice versa.

Profitability Coefficient : $\mathbf{P C}=\mathbf{D} / \mathrm{H}$. The coefficient of profit is a comparison 
between the net profit that is actually received by the producer and his social net profit. If the value of $\mathrm{PC}>0$ indicates that overall government policy provides incentive to producer.

Subsidy Ratio to Poducer : SRP = L/E = (D-H)/E. SRP is an indicator that shows the proportion of receipts at the social price needed if subsidy or tax is used as a substitute for government policies. The SRP value positively indicates a positive impact of government policy.

\section{RESULTS AND DISCUSSION .}

Respondents of this study were farmers who planted soybeans. The respondents' identity can be explained by several characteristics, namely the age of the respondent, the education level of the respondent, farming experience and the amount of land ownership. Data can be seen in Table 3.

Based on the observations of 100 respondents, it was noted that the age of soybean farmers was around 30-60 years. The age of the respondent was the most in the age range of 31-60 years as many as 71 persons or $71 \%$ who were of productive age. Productive age affected the physical abilities of farmers in managing their farming. Kurniati (2015) argued that farmers who work in productive age will be better and maximum compared to nonproductive age.

The education level of the respondents consisted of respondents graduated from elementary school as many as 66 persons $(66 \%)$, graduated from junior high school as many as 20 persons (20\%), graduated from senior high school as many as 13 persons $(13 \%)$ and collage was 1 person $(1 \%)$. The higher the education of farmers, the better the farmers in adopting technology and information related to the success of their farming. The average soybean farmer respondents were graduated from elementary school. It was not different from the results of the Sukmaya study (2016) in Lamongan Regency that stated that the majority of soybean farmers in Lamongan Regency only study up to the elementary level which was equal to $66 \%$ of the total farmer respondents.

Table 3. Respondent Identity in Research Area.

\begin{tabular}{|c|c|c|c|}
\hline $\mathrm{No}$ & Description & Total & Percentage \\
\hline & & ---person--- & $---\%---$ \\
\hline \multirow[t]{4}{*}{1} & Age (year) & & \\
\hline & - $15-30$ & 1 & 1 \\
\hline & - $31-60$ & 71 & 71 \\
\hline & - $>60$ & 28 & 28 \\
\hline \multirow[t]{5}{*}{2} & Formal Education & & \\
\hline & - Elemntary School & 66 & 66 \\
\hline & - Junior High School & 20 & 20 \\
\hline & - Senior High School & 13 & 13 \\
\hline & - College (S1) & 1 & 1 \\
\hline \multirow[t]{4}{*}{4} & Year of Farming (year) & & \\
\hline & - $1-20$ & 8 & 8 \\
\hline & - $21-40$ & 59 & 59 \\
\hline & - $>40$ & 33 & 33 \\
\hline \multirow[t]{4}{*}{5} & Land area (ha) & & \\
\hline & - $<0,25$ & 25 & 25 \\
\hline & - $0,26-0,5$ & 57 & 57 \\
\hline & - $>0,5$ & 18 & 18 \\
\hline
\end{tabular}

Source: Processed Primary Data, 2018. 
Table 4. Policy Analysis Matrix Analysis of Soybean Agribusiness in Grobogan District.

\begin{tabular}{cccccc}
\hline & & \multicolumn{2}{c}{ Cost } & \\
\cline { 4 - 5 } $\mathrm{N}$ & \multirow{2}{*}{ Description } & $\begin{array}{c}\text { Output } \\
\text { o }\end{array}$ & $\begin{array}{c}\text { Tradeable } \\
\text { Input (Rp) }\end{array}$ & $\begin{array}{c}\text { Nontradeable } \\
\text { Input (Rp) }\end{array}$ & Benefit (Rp) \\
\hline 1 & Private cost & $7.322 .237,10$ & $441.200,00$ & $5.190 .643,88$ & $1.690 .393,22$ \\
2 & Social cost & $6.144 .117,27$ & $599.348,16$ & $4.904 .173,88$ & $640.595,23$ \\
3 & Policy Impact & $1.178 .119,83$ & $-158.148,16$ & $286.470,00$ & $1.049 .797,99$ \\
\hline
\end{tabular}

Source: Processed Primary Data, 2018.

Table 5. Private Cost Ratio (PCR) and Domestic Resource Cost Ratio.

\begin{tabular}{lc}
\hline \multicolumn{1}{c}{ Criteria } & Score \\
\hline $\begin{array}{l}\text { Private Cost Ratio } \\
\text { (PCR) }\end{array}$ & 0,75 \\
BSD (DRCR) & 0,88 \\
\hline
\end{tabular}

The experience of farming respondent for 1-20 years as many as 8 persons (8\%), for 21-40 as many as 59 persons $(59 \%)$ and for $>40$ years as many as 33 persons $(33 \%)$. Most experience in farming was in the range of $21-40$ years. The duration of farming will affect the level of knowledge and experience of farmers in carrying out their farming.

The average land area owned by soybean farmers in the study area was 0.4 ha. There were 25 persons $(25 \%)$ who had an area of $<0.25$ ha, 57 people $(57 \%)$ who had a land area of $0.26-0.5$ ha and 18 people who had land> 0.5 ha. The type of land owned was rainfed paddy field that had 3 planting seasons with a rice-cornsoybean pattern.

Private and Social Benefit of Soybean Farming Business in Grobogan District . The results of the analysis using the Policy Analysis Matrix (PAM) of soybean farming business conducted in Grobogan Regency was profitable and feasible to be cultivated, this was indicated by the results of the analysis of private benefit and social benefit that were positively valued. The results of profit analysis using farming analysis soybeans can be seen in Table 4.

Based on Table 4, it can be seen that farming business income calculated using private price was $\mathrm{Rp} 1,690,393.22$ per planting season while farming business income calculated using social prices was Rp.640,595.23 per hectare 0.4 ha per planting season. This income was greater than Firdaus's research (2007) with private income from farming business in Jember, which amounted to Rp. 550,475.46 per ha and in Banyuwangi amounted to Rp153,180.66 per ha. Farming business income that calculated based on social prices in Jember was Rp. $189,769.57$ per ha and in Banyuwangi was (Rp. 975,672.95) per ha. Higher private income compared to social income showed that farming carried out in Grobogan Regency was more efficient and had a high comparative advantage. It was in accordance with the opinion of Suhardedi et al. (2017) which stated that a farming business that had a private advantage of more than 0 and was higher than its social benefits showed that the farming activity was already efficient and had a comparative advantage. This difference in the cost of private and social benefits was supposed due to the influence of government policies, especially in the form of subsidy.

\section{Competitiveness of Soybean Farming} Business in Grobogan District. Analysis of competitive advantage of a commodity can be seen from Private Cost Ratio (PCR) and comparative advantage can be seen from the Domestic Resource Cost Ratio (DRCR). Based on the results of the analysis can be seen in Table 5 .

Based on Table 5 above, it can be seen that the PCR (Private Cost Ratio) value 
was 0.75 . The value less than 1 indicated that soybean farming in Grobogan Regency had a competitive advantage. It was in accordance with Firdaus's opinion (2007) which stated that the decision criteria for PCR are if the PCR value was $\leq 1$, there was a competitive advantage in soybean products. The PCR value of 0.75 means that to produce one-unit value-added output in private prices, domestic Sourcedaya factor needs 0.75 units. This means that the cost can be saved as much as 0.25 units or equal to $\mathrm{Rp}$. 3,277.02. This value based on the assumption of the rupiah exchange rate in the year used in this study of US \$ was Rp. 13.108.05. This value was higher than the research of Ratna et al. (2013) regarding the competitiveness of soybean in Sumenep Regency, namely the PCR value of 0.56 , which means that to produce one unit of value-added output at private prices required a resource factor of 0.56 units or can save 0.46 units. The results of Firdaus's research (2007) also showed a greater PCR value, namely the value of PCR in soybean farming in Jember that was equal to 0.87 and in Banyuwangi that was equal to 0.96 . Based on the PCR value, it can be seen that soybean farming in Grobogan Regency produces soybean that was able to compete, because soybean farming was considered to have conformity with land and domestic resource.

Government Policy for Output and Input. Based on the analysis, it can be seen that the impact of government policy on soybean farming in Grobogan Regency was as follows:

Government Policy for Output. The effect of government policy on the market mechanism on soybean output in Grobog Regency can be known by the value of NPCO (Nominal Protection Coefficient for Output). The result of the NPCO value was 1.19; this value was more than one which indicated that there was a government policy that protects output or the private price received by farmers was higher than social prices. The NPCO value was 1.19 it means that the farmer gets a price 19\% higher than the world price. This was due to the government's efforts to overcome the drop in soybean prices that farmers often complain about giving Government Purchase Price regulations that refer to the Ministry of Trade Regulation of Republic of Indonesia (Permendag) Number 27/M-DAG /PER/5/2017 of Rp.8,500.00 per kg. But the local government of Grobogan Regency in an effort to maintain price set the selling price of soybeans, which amounted to Rp.7,400.00 as the agreement with Bulog and soybean entrepreneurs.

Table 6. Government Policy for Soybean Farming Business.

\begin{tabular}{lr}
\hline \multicolumn{1}{c}{ Criteria } & Score \\
\hline Output Transfer (OT) & $1.178 .119,83$ \\
Input Tradeable Transfer (IT) & $(158.148,16)$ \\
Input Non tradeable Transfer (FT) & $286.470,00$ \\
Net Transfer (NPT) & $1.049 .797,99$ \\
Nominal Protection Coefficient for Output (NPCO) & 1,19 \\
Nominal Protection Coefficient for Input (NPCI) & 0,74 \\
Effective Protection Coefficient (EPC) & 1,24 \\
Profit Coefficient (PC) & 2,64 \\
Subsidy Ratio for Producers (SRP) & 0,17 \\
\hline
\end{tabular}

Source: Processed Primary Data, 2018. 
Government Policy for Input. The results of the analysis showed that the value of NPCI was less than 1 . This showed that the government's policy on tradeable inputs had a positive impact on soybean farming in Grobogan Regency. The NPCI value of soybean farming in Grobogan Regency was 0.74, which means that farmers buy tradeable inputat a price of $24 \%$ lower than the price of social input. It was due to the subsidies of production facilities from the government, namely certified soybean seeds and NPK fertilizers obtained by farmers through the Definitive Plan for Group Needs (RDKK) according to applicable regulations (Directorate General of Food Crops, 2017).

Overall Government Policy for Output and Input.The overall output and input policies can be seen through several indicators such as Effective Protection Coefficient (EPC), Net Protection Transfer (NPT), Profit Coefficient (PC), Subsidy Ratio to Producer (SRP).

Effective Protection Coefficient (EPC). EPC or effective protection analysis was used to determine the effect of overall government policy and market input output mechanisms. EPC showed government policy of providing incentives or disincentives to soybean farming in Grobogan Regency. Based on Table 5 showed that the EPC value was 1.24. It showed that the EPC value of soybean farming business in Grobogan Regency was more than one, that meant there was a positive impact of government policy in price formation and the commodity market mechanism had provided incentives (protection) to soybean farmers to develop their farming. EPC value of 1.24 indicated that the government provides incentives effectively to farmers, because there was added value perceived by farmers by $24 \%$ higher than their social added value.

Net Protection Transfer (NPT). NPT is a value that describes the increase or decrease in producer surplus caused by government policies. Based on the results of the analysis shown in Table 16, it showed that the value of the NPT was Rp1,049,797.99. The value indicated a positive NPT. This was due to the policy of trade-in inputand the price of soybean output in Grobogan District at the farm level which was higher than the social price.

Profit Coefficient (PC). PC value was used to find out the comparison between private benefit and social benefit. Based on the results of the analysis, it was known that the $\mathrm{PC}$ value for soybean farming in Grobogan Regency was 2.64. PC valuemore than 1 indicated that the existence of government policies that lead to private profits was higher than social benefits. PC value showed a value of 2.64 which means that farmers obtain higher private benefits almost 3 times greater than their social benefits.

Subsidy Ratio to Producer (SRP). SRP is a ratio used to measure all transfer effects. This ratio was the ratio between net transfer and output value at the world price level. SRP showed the extent of the income from the system increase or decrease due to the effect of transfers. Based on the results of the analysis the SRP value was 0.17 which means positive. A positive SRP value indicated protection from the government which can reduce production cost. The SRP value of 0.17 means that there was a government policy to reduce production cost by $17 \%$ for every kilogram of production.

\section{CONCLUSION}

Based on the results of the analysis and discussion some conclusions can be drawn as follows:

1. Soybean farming in Grobogan Regency has positive and efficient private benefits, amounting to Rp1,690,393.22. This positive value can be interpreted that soybean farming in Grobogan Regency is profitable.

2. The value of Private Cost Ratio (PCR) of soybean farming in Grobogan 
Regency was 0.75 that showed a smaller value than 1 , it means that soybean farming was financially efficient or had a competitive advantage and can spur production growth. The value of DRCR (Domestic Resource Cost Ratio) was 0.88 that showed a value of less than one, it means that soybean farming was economically efficient or had a comparative advantage.

3. Government policy had a positive impact or take sides with soybean farming both in terms of output and tradeable inputs, this is indicated by the NPCO value (Nominal Protection Coefficient Output), EPC (Effective Protection Coefficient) and PC (Profit Coefficient) greater than one, NPCI (Nominal Protection Input Coefficient) is less than one and NPT (Net Protection Transfer) and SRP (Subsidy Ratio to Producer) values showed positive result.

\section{REFERENCES}

Badan Pusat Statistik. 2014. Kabupaten Grobogan Dalam Angka Tahun 2014. BPS. Kabupaten Grobogan

Badan Pusat Statistik. 2016. Kabupaten Grobogan Dalam Angka Tahun 2015. BPS. Kabupaten Grobogan

DirektoratJenderalTanamanPangan. 2017. PetunjukTeknisPengelolaanProduksi Aneka Kacang dan Umbi.http://tanamanpangan.pertanian.go.id/assets/front/uploads/document/Juknis\%20Kedela i\%202017\% 200K\%20.pdf. Diakses pada 20 Mei 2018.

Firdaus, M. 2007. Analisis daya saing kedelai JawaTimur. J. SEP 1 (2) : 16-27.

Gittinger, J. P. 1986. Analisa Ekonomi Proyek-Proyek Pertanian. UI Press.

Kadariah. 2001. Ekonomi Perencanaan. Jakarta, LPEE Universitas Indonesia.

Kurniawan, Y.A. 2011.Analisis daya saing usahatani jagung pada lahan kering di Kabupaten Tanah Laut Kalimantan Selatan. J. AgribisnisPedesaan 1 (2) : 83-99.

Kurniati, D. 2015. Perilaku petani terhadap risiko usahatani kedelai di Kecamatan Jawai Selatan Kabupaten Sambas. J. Social Economic of Agriculture 4 (1) : 32-36.

Nugraha, T.A. 2015.Analisis KeuntungandanDayaSaingUsahataniBuah Naga di Desa Marga Jasa Kecamatan Sragi Kabupaten Lampung Selatan. Program Sarjana Universitas Lampung, Bandar Lampung. (SkripsiSarjanaPertanian).

Porter, M.E. 1990. The Competitive Advantage of Nations. The Free Press, New York.

Pearson S., C. Gotsch, S. Bahri. 2005. Aplikasi Policy Analysis Matrix pada Pertanian Indonesia. Yayasan Obortani Indonesia, Yogyakarta.

Ratna, P., R. Santosa, D. Wahyudi. 2013. Daya saing kedelai di Kecamatan Ganding Kabupaten Sumenep. J. Cemara 10 (1) : 18-35.

Riduwandan Engkos.2011.Cara Menggunakan dan Memaknai Analisis. J. Alur Alfabeta, Bandung.

Riyanto, B. 2001. Dasar - Dasar Pembelanjaan Perusahaan. BPFE Yogyakarta, Yogyakarta. 
Rukmana, R dan Y. Yuniarsih. 2012. Kedelai :Budidaya dan Pasca Panen. Kanisius, Yogyakarta.

Sahaya, H.N. 2014. Pengembangan usahatani kedelai di Kabupaten Grobogan sebagai upaya mewujudkan ketahanan pangan nasional. J. Ekonomi Pembangunan 3 (2) : 252-258.

Sari, B.J.W.P. dan S.D.W. Prajanti. 2016. Analisis keunggulan kompetitif usahatani kedelai Indonesia. J. Ekonomi Pembangunan 17 (2) : 143-151.

Soekartawi. 2002. Analisis Usahatani. UI Press, Jakarta.

Soetriono.2006. Daya Saing Pertanian dalam Tinjauan Analisis. Bayumedia Publishing, Malang.

Suhardedi, C., D.H. Darwanto dan Irham. 2017. Daya Saing Usahatani Padi di Kabupaten Sragen. J. Agro Ekonomi 28 (1) : 19-31.

Sukmaya, S.G. 2016. Daya Saing dan Dampak Kebijakan Komoditas Kedelai Domestik di Kabupaten Lamongan Provinsi JawaTimur. Program Pascasarjana Institut Pertanian Bogor, Bogor. (Tesis Magister Sains). 